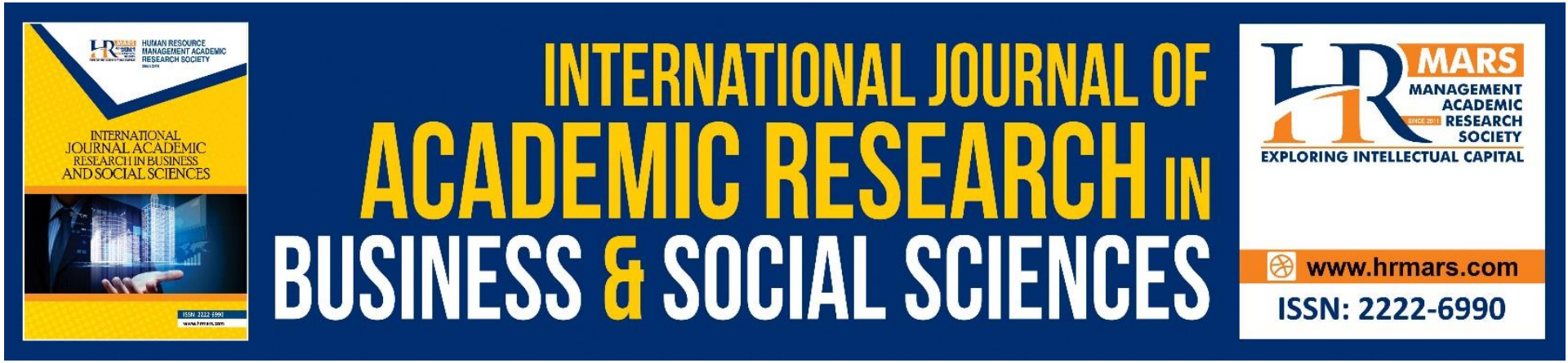

\title{
Developing the Steam-Based Learning Handbook with The Help of Loose Parts During the Covid-19 Pandemic
}

\author{
Indriani Puspita Hafidz, Kamariah Abu Bakar
}

To Link this Article: http://dx.doi.org/10.6007/IJARBSS/v11-i11/10550～DOI:10.6007/IJARBSS/v11-i11/10550

Received: 04 September 2021, Revised: 01 October 2021, Accepted: 28 October 2021

Published Online: 21 November 2021

In-Text Citation: (Hafidz \& Bakar, 2021)

To Cite this Article: Hafidz, I. P., \& Bakar, K. A. (2021). Developing the Steam-Based Learning Handbook with The Help of Loose Parts During the Covid-19 Pandemic. International Journal of Academic Research in Business and Social Sciences, 11(11), 2030-2046.

Copyright: (C) 2021 The Author(s)

Published by Human Resource Management Academic Research Society (www.hrmars.com)

This article is published under the Creative Commons Attribution (CC BY 4.0) license. Anyone may reproduce, distribute, translate and create derivative works of this article (for both commercial and non0-commercial purposes), subject to full attribution to the original publication and authors. The full terms of this license may be seen

at: http://creativecommons.org/licences/by/4.0/legalcode

Vol. 11, No. 11, 2021, Pg. $2030-2046$

http://hrmars.com/index.php/pages/detail/IJARBSS

JOURNAL HOMEPAGE

Full Terms \& Conditions of access and use can be found at http://hrmars.com/index.php/pages/detail/publication-ethics 


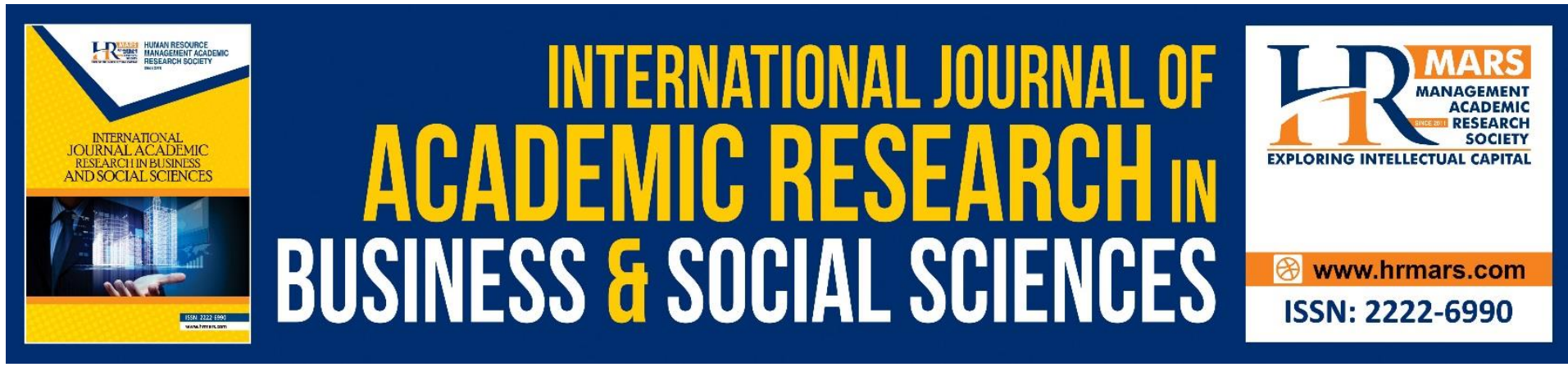

\title{
Developing the Steam-Based Learning Handbook with The Help of Loose Parts During the Covid-19 Pandemic
}

\author{
Indriani Puspita Hafidz, Kamariah Abu Bakar \\ Faculty of Education, Universiti Kebangsaan Malaysia (UKM) Bangi, Malaysia \\ Email: kamariah_abubakar@ukm.edu.my
}

\begin{abstract}
STEAM-based learning with loose parts is one of the learning methods by utilizing teaching materials that come from the material container. These materials are easy to move and manipulate where the child determines the method of use. This study aims to produce learning handbook products for teachers and parents. This research is a research design and development (DDR) which adopts the ADDIE model. The research subjects consisted of 3 teachers and 17 parents at a kindergarten located in East Lombok, NTB, Indonesia. Data collection methods taken are interviews and questionnaires. The results of the analysis carried out show that: (1) The results of the assessment in the form of evaluation scores related to the usefulness of the handbook carried out by material experts are 58, while by media experts are 94 where both meet the "Good" category; (2) Experiments conducted on teachers and parents as practitioners showed that the handbook was categorized as "Good" for use in loose parts-assisted STEAM-based learning with an average score of 50.06. The STEAM-based learning handbook is assisted by loose parts so that it can be used as a learning innovation during the Covid-19 pandemic as an effort to increase the knowledge and information of teachers and parents. It is hoped that further researchers will examine the development of similar handbooks in improving various other aspects.
\end{abstract}

Keywords: Handbook, STEAM, Loose Parts, Covid-19 Pandemic

\section{Introduction}

The golden age of a child cannot be repeated and passed away considering this only happens once in his life. Various stimuli are needed to create optimal development, along with the rapid development of the 21st century which brings various changes and progress in demanding every human being to be more efficient. This is an effort to answer the challenges in the 21st century where humans who have skills in life and career, as well as skills in learning, are needed human resources. However, as it is known that the current situation makes it impossible for the learning process to be carried out directly or face to face. This is especially the case in the world of education in all countries which experience limitations in the process of learning activities in the classroom due to Corona Virus Disease 2019 (Covid 19). The increasingly rampant Covid-19 outbreak has forced everyone to carry out activities remotely 
from home. Changes in the process of learning activities carried out at home or in Indonesia known as Learning From Home (BDR) or Distance Learning (PJJ) can be interpreted as learning that only uses various media to build interaction between teachers and children with situations separated by distance and place. different (Prawirogi, 2020). Therefore, learning at every level of education starting from early childhood education to tertiary education must be carried out following circular letter number 4 of 2020 issued by the Indonesian Minister of Education and Culture, which is related to the implementation of education policies in an emergency due to the spread of Covid 19.

So many school institutions carry out the process of learning activities through technology media, such as zoom applications, google meetings, WhatsApp groups, telegrams, and various other technology platforms. In this case, some schools already have solutions to problems that arise as a result of the process of distance learning activities, such as visits to children's homes alternately based on a regular schedule by implementing health protocols, namely using masks, washing hands before and after meetings where some teachers also provide worksheets for students (LKA) as learning activities at home (Nahdi et al., 2020).

In addition, the cooperation of parents to participate in coaching related to learning activities that are given once a week is also very much needed. Lack of cooperation between parents and teachers will provide difficulties during the learning process, including supervision of children. In this case, communication that is not integrated into the widespread use of tools and materials often occurs, where children's learning outcomes are only embedded in children's worksheets (LKA). According to Indrayasa \& Suryanti (2020), some parents think that problems in education are only the responsibility of schools and teachers. Of course, this is a very worrying problem. Therefore, the role of cooperation between parents and teachers in arranging learning activities to attract interest and provide opportunities for children to explore the environment optimally while studying at home can be said to have not been well integrated. Distance learning (PJJ) during the COVID-19 pandemic requires more creative and innovative ideas, especially in planning learning models by teachers in collaboration with parents. Jessica \& Adhe (2020) states the same thing, where LKA assignments cover as much as 85 percent of all learning activities in schools which ultimately make children feel bored or bored due to monotonous learning activities due to the absence of renewal of the learning process.

Based on the various problems that have been described, it is necessary to stimulate learning activities during the covid-19 pandemic for distance learning following the demands of modern progress. Moreover, one of the learnings with the right approach for the 21st century as it is today is through Science, Technology, Engineering, Arts, Mathematics (STEAM) which can be applied with loose parts media. Loose parts are elements of STEAM-based learning that suggest more fun activities where children are given the freedom to explore various loose materials or their environment. According to Helista (2019), STEAM-based learning can support children to develop knowledge about their environment by observing, asking questions, and researching new things they know. Teachers thus need to provide more opportunities for children to always try even though mistakes will still be found, continue to provide motivation, and let children continue to repeat them (Amini 2014). The loose part according to Daly and Beloglosyky (2015) can support children's ability to think imaginatively and see solutions where this is a form of sensation for children to explore widely so that they can enjoy the world of children's games.

In addition, Adnan et al (2016) also explained that early childhood can be initiated to be introduced to STEM education considering their high curiosity where they tend to like to ask 
various things to adults, especially teachers and parents about experiences and results of exploration in their environment. However, not all teachers and parents have good knowledge and understanding of how to properly implement STEAM. Ramli et al (2017) stated in their findings that readiness among teachers in implementing STEAM education is still low where it is found that only three out of ten teachers are ready to have STEAM education implementation skills in their classrooms. Seven teachers, in this case, stated that they did not have the expertise or confidence regarding the application of STEAM knowledge.

Thus, referring to the basis of this research innovation, the researcher focuses on studying the development of handbooks for STEAM-based learning with the help of loses parts. This is the development of a handbook that contains learning materials about STEAM with loose parts components as well as examples of activities with steps for implementing learning. According to Wyles (2012), it is explained that the handbook can provide explanations and visual demonstrations that refer to the experiences of teachers, parents, and children. Arsyad (2006) adds that the handbook for teachers and parents has a role as a source of information related to the subjects being taught as well as in providing guidance and assistance to teachers and parents during the process of learning activities. As a reference in the process of learning activities, this handbook facilitates one-way and integrated communication and information between teachers and parents in providing material as a loose part of the media tool during the COVID-19 pandemic, such as distance learning.

\section{Literature}

The learning process must play a good role in equipping children with life skills that are adapted to the environment and the child's time needs. In other words, the learning process must be beneficial for children so that educational goals can be achieved effectively and efficiently (Artobatama, 2018). Previous research found that there was little research related to the development of STEAM-based learning handbooks with the help of loose parts for teachers and parents so that they actively help children learn from home.

\section{STEAM (Science, Technology, Engineering, Arts and Mathematics)}

The term STEAM-based learning is one form of approach that is currently focused on various levels of education, from preschool to post-doctoral levels, both informal and non-formal learning settings (Gonzalez \& Kuenzi, 2014). Quoted from Campbell's research (2018), it is stated that many studies related to STEAM have been carried out as an effort to instill the value of future learning that can be done by teachers by involving children in their knowledge and interests. STEAM learning is in line with Helen's (2018)'s opinion which states that in every teaching and understanding that is integrated into the early childhood education curriculum, creating appropriate learning strategies has the aim of teaching children to be able to think critically and have techniques or plans to solve problems. Thus, Alice (2016) describes that STEAM learning can naturally occur when children carry out daily play activities. By exploring new things, it can provide opportunities for children to try to gain experience and knowledge through their play. In addition, teachers and parents should also provide support in child development by understanding and applying the five components of the STEAM model, including involvement, exploration, explaining, detailing, and evaluation.

\section{Loose Parts}

As one of the important elements in STEAM learning, loose parts are various types of openended objects that are easily found anywhere in the environment, because natural resources 
are full of loose parts, such as branches, pine cones, shells, stones, leaves, flowers, and natural objects. other. In addition, teachers and parents can assemble loose parts for free, and make them objects of open-ended activities so that it is unpredictable about what children will do next (Kiewra \& Vaseack, 2016). "The loose parts theory was first proposed by Nicholson in 1971 where the basis is to give children a place to express their creativity by manipulating, changing, and re-engineering materials (Gull, C., Bugonovich, J., Goldstein, S. L., \& Rosengarten, T., 2019). Loose parts are also known as a method to support the development of children's relationships with the environment because loose parts have no rules relating to their use or application. Caser and Robinson (2016) explain that it is important to provide children who need an environment for them to interact or communicate directly when playing with loose parts. Besides being able to optimize children's senses and sensors because of the open-ended loose parts materials, the loose part method is also known to be able to identify and help children explore the process of achieving their respective stages of development.

\section{Guide Book}

The learning guide serves as a reference for teachers and parents through various structured materials and activities. This is like the opinion of Prastowo (2015) which states that the function of the handbook is as a tool for educators where its implementation contains a curriculum to be used as a reference, a form of technical analysis, and teaching methods used by educators. Meanwhile, Ruyattman (2013) stated that the handbook contains practical instructions for carrying out an activity.

In line with the statement above, Afandi (2011) states that books that focus on certain areas have various components and appropriate rules. Thus, the handbook can be said to be a general book that contains various textbooks that can provide clear guidance to tutors, both teachers, and parents.

\section{The Role of Teachers and Parents in Supporting STEAM-based Learning using Loose Parts Material}

Teachers and parents can identify how children experience using loose parts material when planning the learning process which is expected to easily help stimulate children to think critically so that they can find problem solutions and interact well. STEAM-based learning assisted by loose parts that are open-ended and independent not only encourages conversation about ideas but also teaches children about values that enable the discovery process (Smith-Gilman, 2018). The use of loose part-assisted STEM-based learning is expected to provide opportunities for teachers and parents to collaborate and communicate more, especially in the face of the COVID-19 pandemic, considering that children study more at home. Sutton (2011) states that a well-established collaboration between teachers and parents will be very helpful in preparing all the requirements for carrying out learning that can expand children's involvement through the use of loose parts so that children become more broad-minded.

\section{Research Methodology}

The design of this research is design and development research (DDR). Richey and Klein (2010) define that DDR as a process to impress and develop a product. In this study, the researcher adopted the design development procedure using the ADDIE model (analysis, design, development, implementation, evaluation) (Dick and Carry, 1996). This model has five stages 
of product development, which consist of analysis, design, development, implementation, and evaluation. The flow in this research and development is depicted in the figure below.

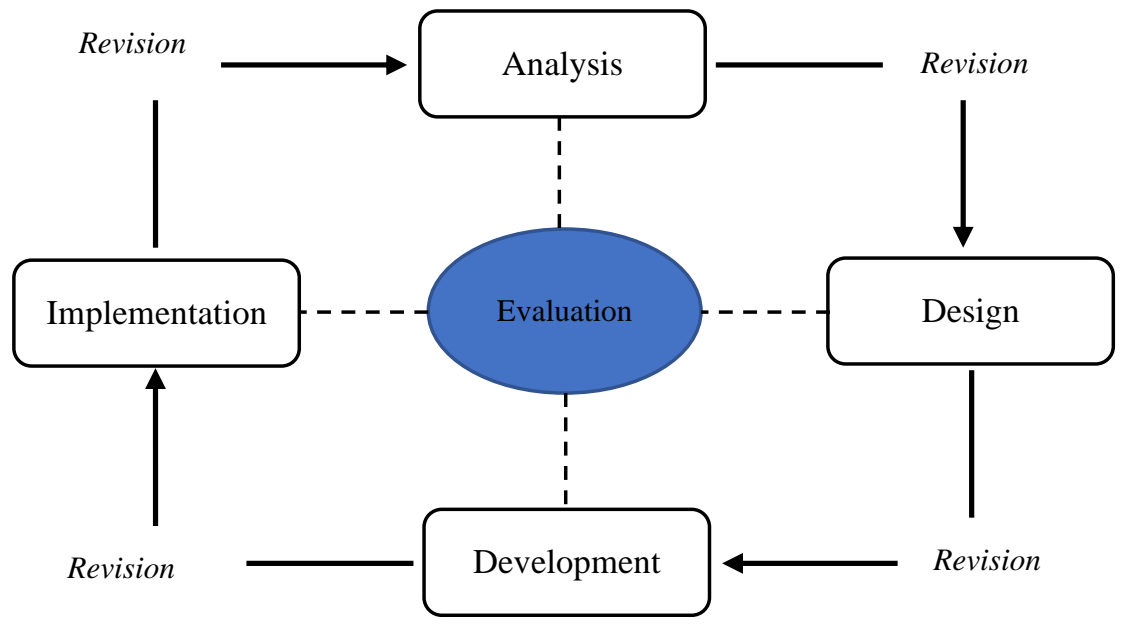

Figure 1. Concept of ADDIE approach (Dick and Carry, 1996)

\section{Analyze}

The analysis stage is carried out to process data to analyze product requirements, user characteristics, and the availability of support for product development. The analysis phase begins with problem discovery that generates insights from various features (Hess \& Greer, 2016).

\section{Design}

The design phase is focused on the concept of construction activities which will be compiled in a STEAM-based learning guide with the help of loose parts. This is adjusted to the objectives to be achieved which then become a reference for teachers and parents in implementing the STEAM learning method with loose parts. This level uses data collected from the analysis phase to obtain theories related to product design (Moradmand, 2014).

\section{Development}

At the development stage, various activities were carried out, among others: (1) searching for and collecting various relevant sources to enrich the material; (2) content production, and illustration image creation; (3) typing and editing; (4) selection of material and size of handbook layout (Muslimin et al., 2017). In line with Widyastuti \& Susiana (2018), it was stated that this stage also includes validation of product drafts that have been developed and will be revised based on input from experts.

\section{Implementation}

The implementation stage is the product testing stage that has been developed where the results of the development will be used to obtain data from research subjects (Sadrianto et al., 2018). The product was tested on teachers and parents by using a questionnaire related to the usefulness of the handbook to be filled in by the teacher with the following evaluation criteria: 1) Attractiveness: clarity of appearance; 2) material presentation: overall material comfort; 3) benefits: behavior change. The feasibility test on teachers is carried out to get 
evaluation and input from teachers and parents to improve and enhance product development.

\section{Evaluation}

The final step is to evaluate to determine the impact and results of the products that have been tested (Wiphasith et al., 2016). This stage includes summative assessment and formative assessment. This type of formative assessment is carried out by entering the existing data at each stage for further use as product improvement. Meanwhile, the type of summative assessment is carried out at the end of the program to determine whether the STEAM-based learning handbook with the help of loose parts is suitable as a guide for teachers and parents. This study also uses formative evaluation because it relates to the stages of development research that is useful for evaluating and improving the development products that have been produced (Braun, 2006).

The test subjects in this study consisted of: (1) Material experts, namely lecturers with minimum criteria who had completed the last master's degree education who understand STEM learning with the help of loose parts; (2) Media experts, namely lecturers with minimum criteria who had completed the last master's degree education who understand media in learning; and (3) Three teachers, seventeen parents at East Lombok, NTB, Indonesia.

Data collection techniques used in this study were online interviews and questionnaires/questions of inquiry. Observations and interviews are aimed at conducting a needs survey analysis. Data in the form of verbal descriptive data were analyzed qualitatively. Meanwhile, data analysis in the form of expert tests and field tests was carried out in a quantitative descriptive manner. The data obtained from the observations were analyzed using descriptive techniques as follows: 1) Collecting data, 2) Copying oral data, 3) Collecting, selecting, and classifying data, 4) Analyzing data and formulating conclusions from the results of the analysis. as a basis for the product, preparation is being developed.

The data from the analysis of product needs from the teacher is used to determine the level of development program needs. The opinions of teachers and parents, in this case, are used to determine specifications and product designs to be developed. Questionnaire data by material experts and media expert validation are used to assess the feasibility of the resulting product to be used as a guide in STEAM-based learning with loose parts assistance which will then be tested by teachers and parents.

The test of the learning handbook in this study was carried out through descriptive analysis. In the product quality test, the data obtained from the numbers are converted into interval data "strongly agree" with a score of 5, "agree" with a score of 4, "neutral" with a score of 3, "disagree" with a score of 2, "strongly disagree with score 1 . The score obtained is then converted using a Likert Scale into a five-point Likert Scale value by referring to the evaluation formula table as follows:

a. $\mathrm{X}$ is the actual score (empirical) that is the total value of the selected scale.

b. $\dot{x}$ is the ideal mean, which is obtained from $\frac{1}{2} x$ (sum of ideal maximum score + ideal minimum score).

c. $\Sigma$ is the ideal standard deviation, obtained from $\frac{1}{6} x$ (sum of the ideal maximum score + ideal minimum score).

$\dot{x}$ is found by the formula: $\dot{x}=\frac{1}{2}$ (Maximum score + minimum score)

$\sigma$ is found by the formula: $=\frac{1}{6}$ (Maximum score - minimum score $)$ 
Table 1. Conversion of scale values

\begin{tabular}{|c|c|c|}
\hline Interval Score & Score & Category \\
\hline $\mathrm{X} \geq \dot{x}+1,8 \sigma$ & $\mathrm{A}$ & Excellent \\
\hline$\dot{x}+0.6 \sigma<\mathrm{X} \leq \dot{x}+1,8 \sigma$ & $\mathrm{B}$ & Good \\
\hline$\dot{x}-0,6 \sigma<\mathrm{X} \leq \dot{x}+0,6 \sigma$ & $\mathrm{C}$ & Fair \\
\hline$\dot{x}-1,8 \sigma<\mathrm{X} \leq \dot{x}-0,6 \sigma$ & $\mathrm{D}$ & Bad \\
\hline $\mathrm{X} \leq \dot{x}-1,8 \sigma$ & $\mathrm{E}$ & Poor \\
\hline
\end{tabular}

(source: Widoyoko, 2009)

Learning guide book products are categorized as valid if the average value obtained from experts and users is at least in the "adequate" category. The results of this evaluation come from material experts, media experts, and users. However, if the evaluation results obtained do not fall into that category, the researcher needs to conduct a review following input from experts and users. The results of data analysis that have not been included in the minimally good category will be used as consideration for conducting product reviews before and after testing before the product developed is finally considered suitable for use.

\section{Findings}

This research was conducted on 3 teachers and 17 parents of students to see the usefulness of the handbook. The data was obtained through a questionnaire usability handbook which was validated by material expert validators and media experts before being used for testing. The next stage in the form of an evaluation stage is carried out by practitioners, including teachers and parents through aspects of assessment with the following criteria: (1) Learning assessment: several examples of learning activities are given to children; (2) Content: the overall convenience of the book material; (3) Appearance: clarity of appearance and appeal of the book. STEAM-based learning handbooks assisted by loose parts are adapted through the ADDIE model procedures or stages (analysis, design, development, implementation, and evaluation). The following are the product development levels of the handbook based on the ADDIE model:

\section{Analysis}

The analysis phase includes: 1) Product needs analysis conducted by 1 teacher and 1 parent. The data obtained based on the results of interviews conducted showed that there was still a lack of understanding about STEAM-based learning assisted by loose parts in every learning process provided by the teacher, both before and during the covid-19 pandemic. Learning is still using conventional methods with children's worksheets (LKA) for each activity so that it can be said that the assistance and guidance to stimulate activities is still not optimal; 2) Analysis of user characteristics (teachers/parents) through observations and interviews with one of the teachers and parents show that the education of 2 out of 3 teachers is not linear in the field of preschool education where they are only high school graduates. On average, parents work more as laborers; 3) Analyzing the availability of support because the school is located in a village with lots of natural materials, including an analysis of facilities to obtain loose parts materials at home and the school environment that supports the process of STEAM-based learning activities with the help of loose parts. 


\section{Design}

The focus of the design phase is to choose the material to be sorted in a STEAM-based learning guide with the help of loose parts that are tailored to the objectives to be achieved, namely as a reference for teachers and parents to accompany children in the learning process from home. In this stage, a strategy for STEAM-based learning activities with the help of loose parts is also chosen, including forms and assessments for each learning activity. After analyzing the level of the problem through interviews with teachers and parents, the results can be taken into consideration in making handbooks that are following the needs of teachers and parents in guiding children. Through this stage, the structure and content of the handbook are provided. The following is the design of the handbook for this research.

Table 2. Handbook Structure Plan

\begin{tabular}{|c|c|c|}
\hline $\begin{array}{c}\text { No } \\
.\end{array}$ & $\begin{array}{c}\text { Arrange } \\
\text { ment }\end{array}$ & Information \\
\hline 1. & Cover & $\begin{array}{l}\text { a. Title: Handbook of STEAM Loose parts } \\
\text { b. Figure: Adapted to the material of loose parts } \\
\text { component }\end{array}$ \\
\hline 2 & $\begin{array}{l}\text { Table of } \\
\text { Contents }\end{array}$ & $\begin{array}{l}\text { a. Page Title (Cover) } \\
\text { b. Preface } \\
\text { c. Instruction of Book Usage } \\
\text { d. Content } \\
\text { e. About this Book } \\
\text { f. Chapter } 1 \text { Introduction : Background, Goals, Scope, } \\
\text { Purpose } \\
\text { g. Chapter } 2 \text { Content: What is STEAM?; Type of } \\
\text { STEAM; What is Loose parts?; Loose parts } \\
\text { components; What is provocation?; What is } \\
\text { Invitation? } \\
\text { h. Chapter } 3 \text { STEAM- Loose parts activity at home; } \\
\text { Example of Activity 1, Example of Activity 2, } \\
\text { Example of Activity 3, Assessment of Loose parts } \\
\text { Kid Activity } \\
\text { i. Closing } \\
\text { j. References }\end{array}$ \\
\hline
\end{tabular}

\section{Development}

At the development phase, activities were undertaken to collect various relevant sources to enrich the material, type, edit, create illustrations, select book sizes and materials and arrange the layout of the handbook. Verification activities are also carried out by material/material expert verifiers and from media experts to obtain input and product reviews before it is tested on teachers and parents.

a. Product production

Based on the product design that has been planned, the product is made. All components that have been completed at the design phase, those are adjusted to material indicators and media indicators to be used by users so that they are easy to understand and apply as activity guides for children to increase creativity when learning from home, further, this book is 
printed in accordance with the target sample. Full color A4 paper and hard cover so that teachers and parents are clearer, interested in reading and using it.

b. Validation

This level was carried out to test the usefulness of learning handbooks based on STEAM with the help of loose parts for teachers and parents. The results of the expert evaluation of manual products are as follows: the comments and recommendations submitted cover all evaluation indicators, namely: (1), inconsistent font type and size; (2) many foreign terms are not italicized; (3) images with overlapping tables; (4) evaluation schedule appears or not in the form of photos; (5) the image should be more presentable; (6) the use of words is still much more precise in accordance with the meaning of EYD, and the use of letter colors is not clear. "Verification was undertaken through a structured questionnaire which will be analyzed to discover the usefulness of the handbook. If a revision is needed, then the input provided by material experts and media members will be a reference in revising the product until finally the product can be said to meet the requirements for testing. The results of the data that have been obtained through material/material validation obtained an overall score of 58 which is in the "Good" category which meets the criteria $x+0,6<X x+1.8$. It can be concluded that the product of the manual in terms of presenting the material is suitable for use in the field or valid tests to be carried out. Meanwhile, the calculation of data obtained from media experts has showed that the second calculation of the score calculation by media experts in the manual STEAM learning assisted by loose parts that has been made and evaluated are as follows: Based on the calculation results, it is known that an overall score of 94 is included in the "Good" category due to it has obtained a score that meets the criteria $\mathrm{x}+0.6<\mathrm{Xx}+1.8$, it is concluded that the product of learning handbook in terms of media presentation is in accordance with the field or legitimate trials to be carried out.

The following is a learning handbook based on STEAM that assisted by loose parts before and after expert assessment/review, namely:

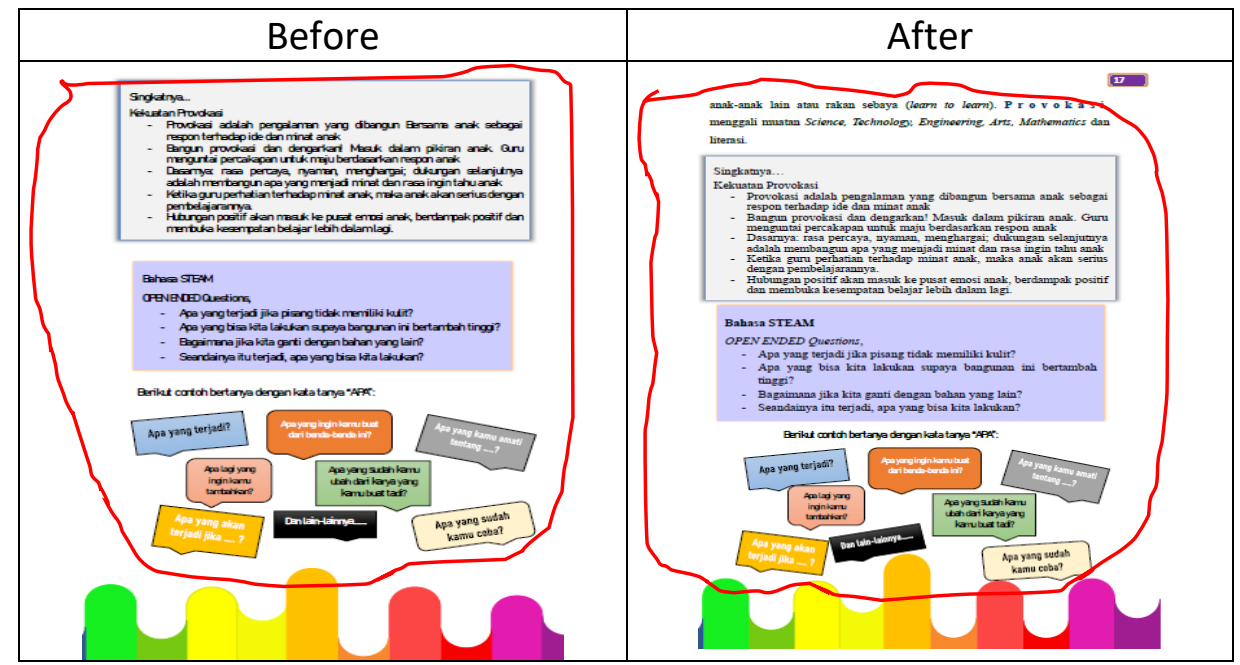

Figure 2. learning handbook based on STEAM that assisted by loose parts prior to and after the revision of "Inconsistent of fonts, types and font sizes"

Description:

(1) Prior to the revision of the use of fonts, the type and size of the fonts were inconsistent

(2) After revision of the use of the font, the type and size of the font is adjusted to use the font type and size of Times New Roman 
INTERNATIONAL JOURNAL OF ACADEMIC RESEARCH IN BUSINESS AND SOCIAL SCIENCES Vol. 11, No. 11, 2021, E-ISSN: $2222-6990$ @ 2021 HRMARS

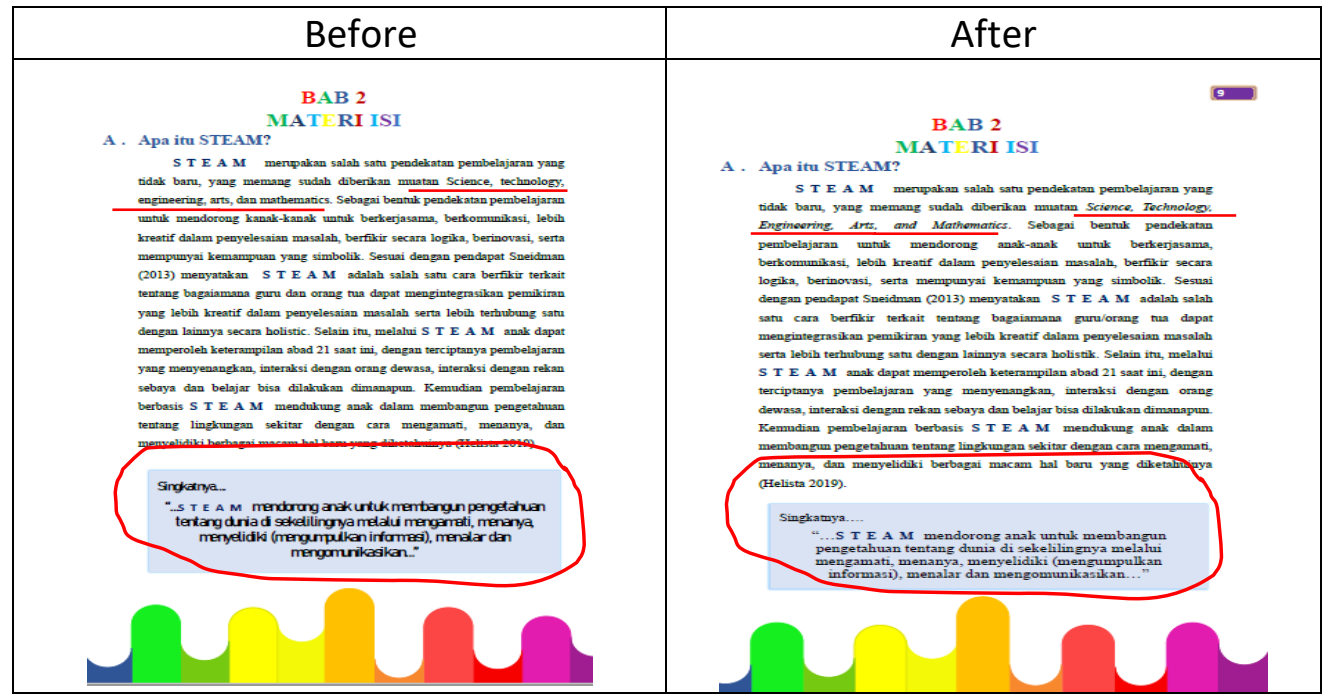

Figure 3. learning handbook based on STEAM with the help of loose parts before and after the revision: "many foreign terms are not italicized"

Description:

(1) Prior to the revision, many foreign terms were not italicized

(2) After revision, all foreign terms are italicized and clearly provide an understanding of the abbreviated form of each STEAM term.

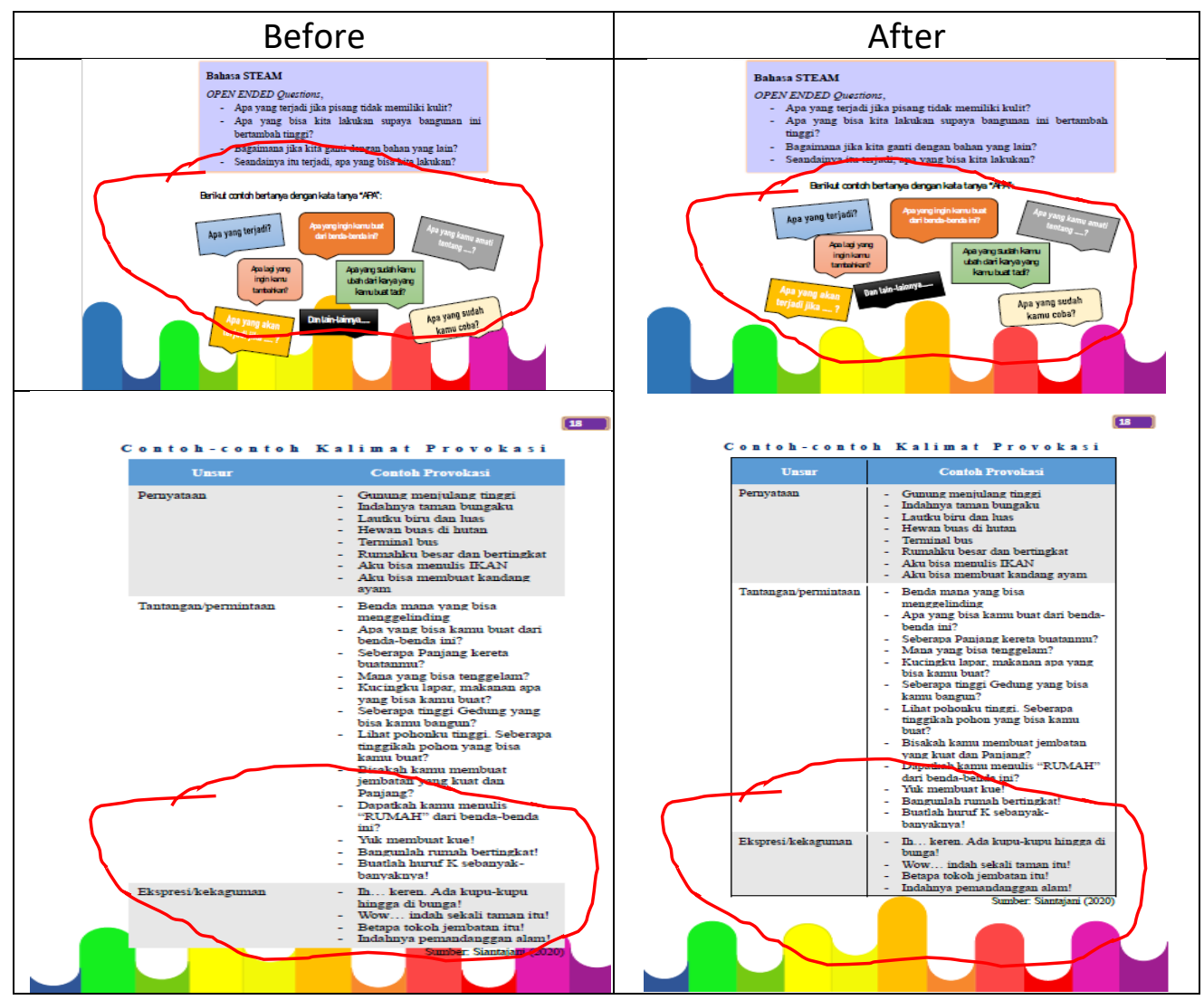

Figure 4. Learning book based on STEAM that assisted by loose parts prior to and after the revision: "figure overlaps with table" 
Description

(1) Before reviewing figure with overlapping and irregular tables.

(2) After the revision of the rules, the tables are compiled and reduced in size so that they do not overlap.

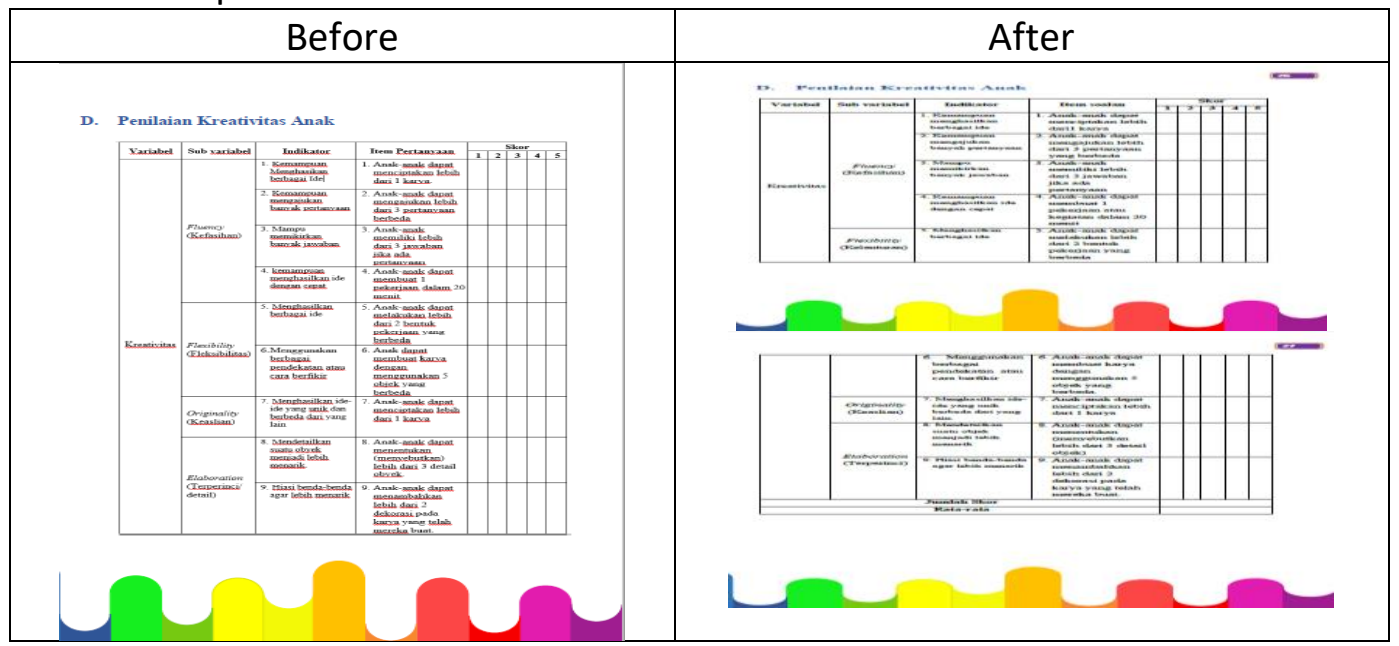

Figure 5. Learning handbook based on STEAM that assisted by loose parts before and before revision: "research table should be presented"

Description:

(1) Before the revision of the assessment format was in the form of pictures and not presented

(2) After the revision of the assessment format has appeared and is clear

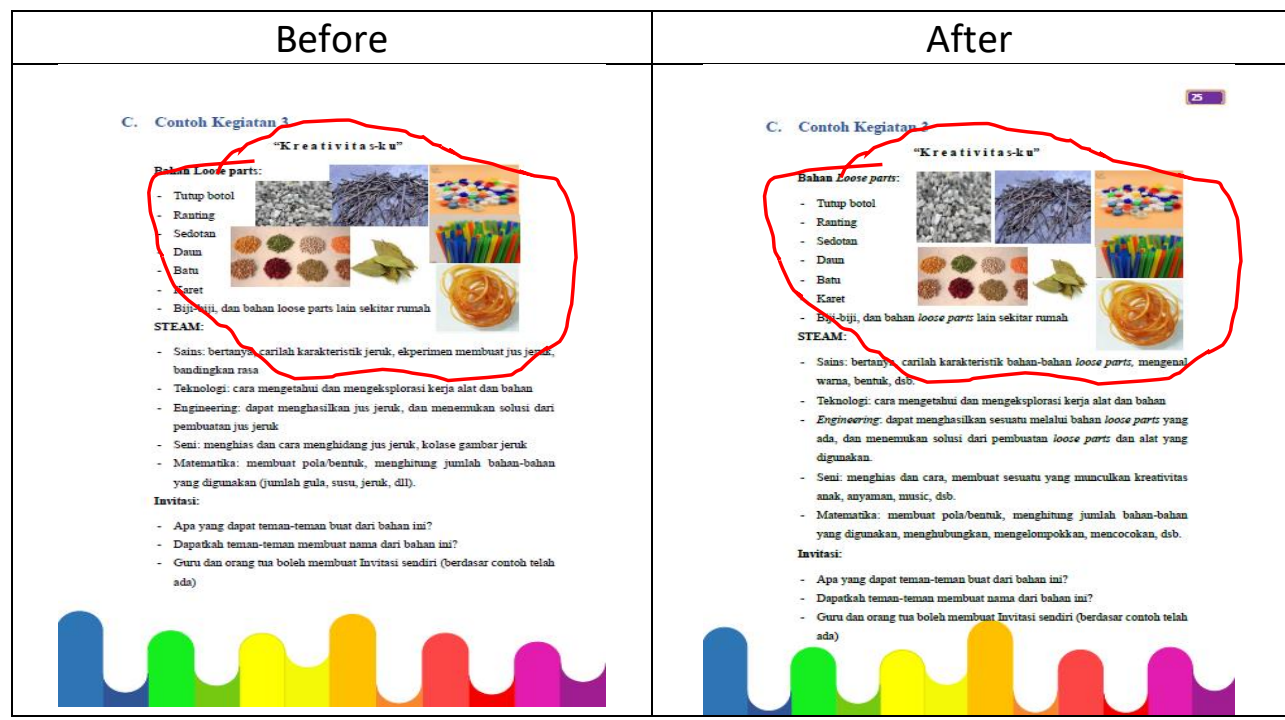

Figure 6. Learning handbook based on STEAM with the help of loose parts before and after revision: "pictures must be presentable"

Description:

(1) Before reviewing, it found the irregular pictures and untidy/arbitrary layout of pictures

(2) After the revision of the picture has been arranged and the location of the picture is the same 


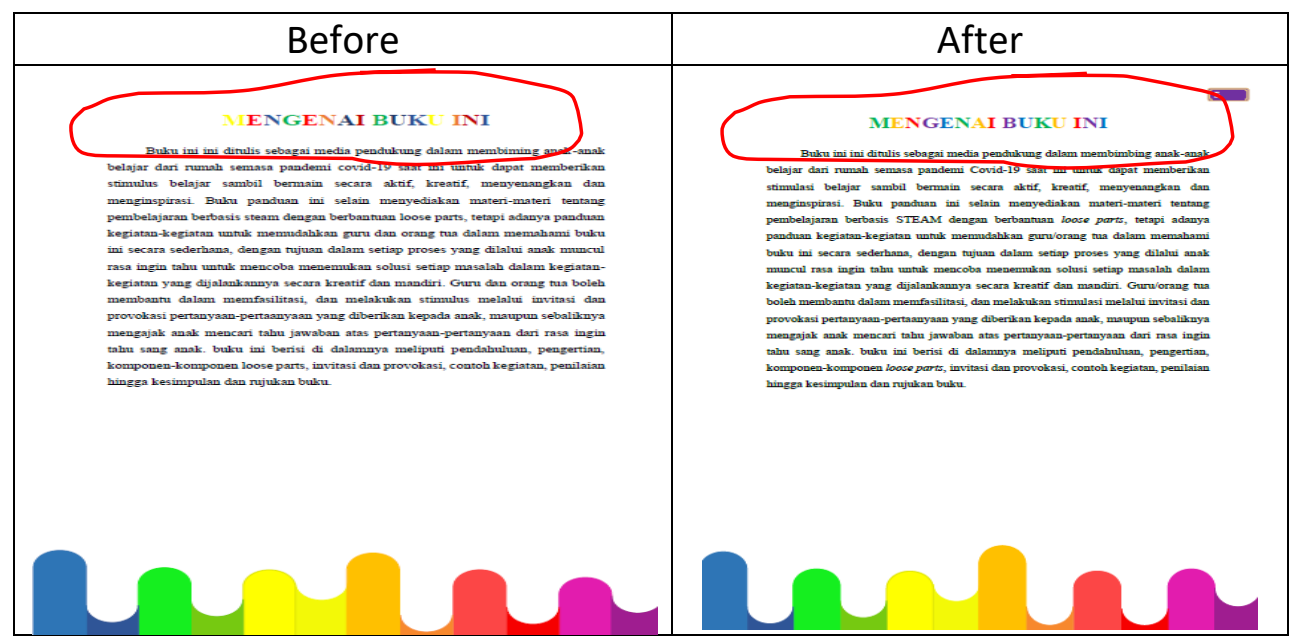

Figure 7. Learning handbook based on STEAM that assisted by loose parts before and after the revision: "The use of words is not accordance with the meaning of EYD and the use of letter colors is not clear when it is read"

Description:

(1) Prior to the revision, the color of the check letter was not legible with $n$ that was clear, because it used yellow.

(2) After the revision, the color is replaced with a fairly clear reading from before.

\section{Implementation}

At this stage, the results of the development were tested on 3 teachers and 17 parents from one of PAUD or Kindergarten in East Lombok, NTB Indonesia by using a questionnaire on the usefulness of the learning handbook to be filled out by teachers and parents to obtain input as material for improving the product draft. From the distributed questionnaires, an average score of 50.06 was obtained in the "Good" category due to it has obtained a score that met the criteria $x+0.6<X x+1.8$ thus, it can be asserted that that the media of this learning handbook is feasible. used by teachers and parents as a guide or reference in teaching and learning based on STEAM with the help of loose parts.

\section{Evaluation}

The evaluation stage is the stage where an assessment is carried out at each stage to carry out each stage correctly before entering the next stage. At this stage, it has been done to see the usefulness of a product. The measurement of the usability of developing learning handbook based on STEAM by using the probability assessment questions as a marker of the level carried out by investigators in measuring the usability of guidebooks for teachers and parents in teaching a learning based on STEAM with the help of loose parts conceptually and structured.

\section{Discussion}

This study aims to identify the design, usability of learning handbook based on STEAM by the help of loose parts. The research findings found that book design could provide an understanding of the implementation of STEAM learning by using materials around the home and school to stimulate children actively and creatively. It is in accordance with Prameswari's opinion (2020) that the open nature of loose parts in the environment can optimize children's five senses and sensors actively to explore and explore further so that children can reach their stage of development. Besides, the learning handbook is a concept that contains practical 
directions for carrying out activities (Ruyattman, 2013). Referring to the opinion that teachers and parents can design innovative learning activities and in practice provide opportunities for children to develop active and critical senses and curiosity through the use of learning handbook. Thus, the design of the learning handbook is adjusted to the analysis of needs that have been known through the results of teacher and parent interviews as a consideration for making designs or contains in the learning handbook based on STEAM with the help of loose part. It is also supported by Wulandari (2017) the quality of the book includes: (1) appropriate and effective teaching procedures to achieve meaningful learning objectives; (2) the function and benefits of the learning handbook; (3) it can support teachers and parents in learning; (4) having elements such as paying attention to the form of good text, pictures and illustrations; and (5) the truth of the material and the appeal in the book. Therefore, according to the results of the analysis of the design of the manual, it can provide clear guidance for teachers and parents.

The development of the learning handbook has undergone through the validation stage to test the product possibility stage carried out by material expert validators and media experts as well as practitioner assessments by teachers and parents regarding the implementation of examination in the large class. The approval by the material expert obtained an overall score that was in the "Good" category, and the total score from the media expert obtained an overall score that both met the criteria, which could be categorized as very valid. The results of the product development manual have been reviewed based on suggestions and comments from material expert validators and media experts aimed at product improvement. Further, the large class experiment was undertaken by practitioners, namely teachers and parents, in carrying out the results of practitioners' assessments regarding the usefulness of the book, they obtained an average score that was in the "Good" category due to they had obtained scores that met the criteria before being tested from the assessment of expert validators and after being tested by practitioners can be categorized as good. In line with this, Arsyad (2013) argues that a product is legitimate if the product meets predetermined criteria, and the use of books can assist teachers and parents in the aspects of designing learning, providing tools and loose parts materials to how to stimulate children in learning various activities (Bahrum \& Ibrahim, 2018). This reveals that the use of the learning handbook is authentic and according to the practical category.

\section{Implication}

The implication of this study is it can provide awareness and benefits to teachers and parents due to the results of the study obtain a positive impression in assisting the process of implementing children's learning from home during Covid-19 with learning handbook based on STEAM with the help of loose parts for children. The study of Damayanti et al. (2020) asserts that distance learning based on STEAM with loose parts media is learning that gives freedom to children in carrying out an activity. In addition, the development of this handbook provides knowledge and understanding to teachers and parents regarding learning based on STEAM and previously the loose parts material is unknown.

\section{Conclusion}

On the whole, this chapter has discussed and explained the study findings, research implications, and suggestions for further studies. Dealing with the discussion above, it is expected that this research can provide great benefits to educator of early childhood education and also parents in carrying out learning from home during this covid-19 period. 
Although the development of learning handbook based on STEAM with the help of loose parts is still not widely studied by people and is used as a continuous practice by educators and parents. Therefore, the findings of this study are expected to be a benchmark for further research in the future that focuses on skills in creativity and several other aspects of child development, so that the quality of the effectiveness of teaching and learning activities can be improved and the realization of teaching knowledge in early childhood education through this learning handbook.

Beside that, this research is expected to obtain contribution in the form of giving easiness to parents and teachers in accompanying and supporting the children studying at home during Covid-19 and STEAM based learning hanbook with loose parts media developed gets good result and feasible to be used by all age categories practically, and attractives to be learnt as guideline in providing various activities to the kids. This book guideline development is influenced by some factors in understanding the integration with basis of science, technology, engineering, art, and mathematics by using various loose parts media material around the environment as an effective approach method with different ways to teach scientifically and freely (independent).

Overall, the research results show that STEAM based hanbook with loose parts media has positively impressive impact for parents and teachers in implementing the learning from home with various materials and examples for the children. However, the limitation of this research is in the implementation and evaluation because the STEM learning method approach with loose parts media is still new for parents and teachers in East Lombok, Indonesia. Besides, the distance of researcher who is residing in Malaysia with target research samples in Lombok, Indonesia causes lateness in the data collection. Aparts from this limitation, this research can add understanding of an effective teaching and learning method during Covid-19 pandemic.

In addition, the researcher would like to suggest that this STEAM based learning hanbook with loose parts media still can be used and implemented with improvisation in accordance with parents' and teachers' creativity in giving attractive learning during at home or at school when it is already safe to enter school for face to face learning process by developing some other aspects of assessment developoment for the children. The researcher also suggests that this handbook needs to be developed and studied through various point of views of educational practitioner parties thoroughly and widely to produce better product in the future to assure STEAM based learning with loose parts media could give more benefits in the teaching and learning process.

\section{References}

Afandi, R. (2011). Integrasi Pendidikan Karakter Dalam Pembelajaran IPS Di Sekolah Dasar. PEDAGOGIA: Jurnal Pendidikan, 1(1), 85. doi:10.21070/pedagogia.v1i1.32

Bahrum, S., \& Ibrahim, M. N. (2018). Kebolehgunaan Modul " steAm " dalam Pengajaran dan Pembelajaran Pendidikan Seni Visual Sekolah Rendah Usability of " steAm " Module in Teaching and Learning of Visual Arts Education in Primary School. KUPAS SENI Jurnal Seni Dan Pendidikan Seni, 6, 65-79.

Braun, V., \& Clarke, V., (2006). Using Thematic analysis in Psychology. Qual Res Psychol, 3(2), 77-101.

Damayanti, A., Rachmatunnisa, S., \& Rahmawati, L. (2020). PENINGKATAN KREATIVITAS BERKARYA ANAK USIA 5-6 TAHUN MELALUI PEMBELAJARAN JARAK JAUH BERBASIS STEAM DENGAN MEDIA LOOSE PARTS. Jurnal Buah Hati, 7(2), 74-90. 
Gonzalez, H. B., \& Kuenzi, J. J. (2014). Science, Technology, Engineering, and Mathematics (STEM) Education: A primer. CS Report for Congress, 97-142.

Gull, C., Bugonovich, J., Goldstein, S. L., \& Rosengarten, T. (2019). Definitions of Loose Parts in Early Childhood Outdoor Classrooms : A Scoping Review. The International Journal of Early Childhood Environmental Education, 6(3), 37-52.

Helista, C. N. (2019). STEAM. In Seminar Nasional: Tiga Pakar Bedah STEAM untuk Anak Usia Dini. Semarang: UNNES.

Hess, A. K. N., \& Greer, K. (2016). Designing for engagement: Using the ADDIE model to integrate high-impact practices into an online information literacy course. Communications in Information Literacy, 10(2), 264-282. https://doi.org/10.15760/comminfolit.2016.10.2.27

Indrayasa, K. B., \& Suryanti, P. E. (2020). Keterlibatan orang tua dalam kegiatan kreatif anak usia dini selama belajar dari rumah. Pratama Widya : Jurnal Pendidikan Anak Usia Dini, 5(2), 180-190.

Jessica, S., \& Adhe, K. R. (2020). PENGEMBANGAN MODUL PEMBELAJARAN BOTANICAPROJECT UNTUK MENSTIMULASI MOTORIK HALUS ANAK USIA DINI. Edukids: Jurnal Pertumbuhan, Perkembangan, Dan Pendidikan Anak Usia Dini, 17(2), 84-95.

Kiewra, C., \& Vaselack, E. (2016). Playing with nature: Supporting preschoolers' creativityin natural outdoor classrooms. International Journal of Early Childhood Environmental Education, 41 (1), 70-95.

Moradmand. (2014). The Design and Implementation of an Educational Multimedia Mathematics Software: Using ADDIE to Guide Instructional System Design. The Journal of Applied Instructional Design, 4(1), 37-49.

Muslimin, M., Nordin, M. N., Mansor, A., \& Yunus, M. (2017). THE DESIGN AND DEVELOPMENT OF MobiEko: A MOBILE EDUCATIONAL APP FOR MICROECONOMICS MODULE. Malaysian Journal Of Learning And Instruction. 221-255. doi:10.32890/mjli.2017.7804.

Prastowo, A. (2014). Metode Penelitian Kualittaif dalam Prespektif Rancangan Penelitian. Yogyakarta: Ar-Ruzz Media.

Prawirogi, A. G. (2020). Efektivitas Pembelajaran Jarak jauh Terhadap Pembelajaran Siswa di SDIT Cebdia Purwarkarta. Jurnal Pendidikan Dasar.

Ruyattman. (2013). Perancangan Buku Panduan Membuat Desain Karakter Fiksi Dua Dimensi secara Digital. Surabaya: Universitas Kristen Petra.

Sadrianto, Rusdinal, Ananda, A., \& Marsidin, S. (2019). Character Work Group Model in Competence Training of Middle School Supervisors. Advances in Social Science, Education and Humanities Research (ASSEHR), 178(1st ICoIE 2018), 644-648. https://doi.org/10.2991/icoie-18.2019.135

Smith-Gilman, S. (2018). The Arts, Loose Parts and Conversations. Journal of the Canadian Association for Curriculum Studies, 16(1), 90-103.

Sutton, M. J. (2011). In The Hand And Mind: The Intersection of Loose Parts And Imagination in Evocative Settings For Young Children. Children Youth and Environments, 408-424.

Widoyoko, E. P. (2009). Evaluasi Program Pembelajaran. Pustaka Pelajar.

Widyastuti, E., \& Susiana. (2019). Using the ADDIE model to develop learning material for actuarial mathematics. Journal of Physics: Conference Series, 1188(1). https://doi.org/10.1088/1742-6596/1188/1/012052 
Wiphasith, H., Narumol, R., \& Sumalee, C. (2016). The Design of the Contents of an e-Learning for Teaching M.5 English Language Using ADDIE Model. International Journal of Information and Education Technology, 6(2), 127-131. https://doi.org/10.7763/ijiet.2016.v6.671

Wulandari, Y. (2017). Kelayakan Aspek Materi Dan Media Dalam Pengembangan Buku Ajar Sastra Lama. Gramatika STKIP PGRI Sumatera Barat, 3(2).

https://doi.org/10.22202/jg.2017.v3i2.2049 